\title{
IMPROVING CLINICAL DRUG DEVELOPMENT REGULATORY PROCEDURES FOR ANTICONVULSANTS
}

\author{
Slobodan Janković, Darko Ilić
}

Faculty of Medical Sciences, University of Kragujevac

\section{ПОБОЉШАЊЕ РЕГУЛАТИВЕ ЗА КЛИНИЧКО ИСПИТИВАЊЕ АНТИЕПИЛЕПТИКА}

\author{
Слободан Јанковић, Дарко Илић \\ Факултет медицинских наука, Универзитет у Крагујевцу
}

\section{ABSTRACT \\ Background: Clinical development of anti- epileptic drugs is demanding due to complex character of the disorder and to diversity of its forms and etiologies.}

Objective: The aim of this review was to suggest improvements in regulatory procedures for clinical development of antiepileptic drugs.

Methods: The following databases of scientific articles were searched: MEDLINE, SCOPUS and SCINDEKS. In total 558 publications were retrieved. The types of articles selected were reviews, reports on clinical trials and letters to the Editor.

Results: There are several changes of regulatory documents necessary for improving process of clinical development of antiepileptic drugs: preference of parallel groups design for add-on trials should be explicit; the noninferiority design for monotherapy clinical trials should be acceptable; restrictive formulations when trials of antiepileptic drugs in children are in question should be avoided; requirements in regard to the efficacy measures should be harmonized among the regulatory bodies; proactive attitude towards discovery of adverse events; and precise requirements for clinical trials specifi- cally designed to prove anti-epileptogenic effects should be made clear.

Conclusion: Current regulatory documents are incomplete in many aspects; an international effort to improve and harmonize guidelines for clinical development of antiepileptic drugs is necessary for improvement of this process.

Key Words: anticonvulsants, clinical development, regulatory documents

\section{САЖЕТАК}

Увод: Клинички развој антиепилептика је захтеван процес због комплексног карактера епилепсије, њених различитих облика и етиологије.

Циљ: Циљ овог прегледног чланка је да укаже на могућа побољшања регулативе клиничког развоја антиепилептика.

Метод: Следеће базе података су претражене: MEDLINE, SCOPUS и SCINDEKS. Укупно је пронађено 558 публикација из категорија прегледни чланак, клиничка студија и писмо аутору.

Резултати: Постоји неколико промена регулативе које су неопходне за побољшање процеса клиничког развоја антиепилептика: у студијама где се нови антиепилептик додаје

Контакт: Слободан Јанковић Факултет медицинских наука, Светозара Марковића 69, Крагујевац, 34000 e-mail: slobnera@gmail.com 
на постојећу терапију треба обавезно применити дизајн са паралелним групама; у студијама са монотерапијом треба доказати да нови лек није мање ефикасан од компаратора; рестрикције везане за клиничке студије код деце треба ублажити; агенције за лекове С.А.Д. и Европске уније треба да ускладе захтеве у погледу мера ефикасности антиепилептика; став према откривању нежељених дејстава нових лекова треба да буде проактиван; захтеви за студије у којима се доказује антиепилептогени ефекат треба да будујаснији.

Закључак: Постојећа регулатива је у много чему некомплетна; неопходан је међународни напор да се побољшају и хармонизују водичи за клинички развој антиепилептика како би се тај процесс побољшао.

Кључне речи: антиепилептици, клинички развој лека, регулатива

\section{INTRODUCTION}

Developing an antiepileptic is more difficult than developing drugs from other therapeutic groups due to chronic character of the disease, its temporal variability in seizure frequency and severity, diversity of seizure types and grave consequences of treatment interruption or nontreatment. The existing regulation of drug development process is based on guidelines for clinical investigation (evaluation) of antiepileptic products issued by the European Medicines Agency (EMA) ${ }^{1}$ and by Food and Drug Administration (FDA) of U.S. Department of Health and Human Services ${ }^{2}$. The guidelines are not too prescriptive, which in some cases could be an advantage, but many problematic issues remain untouched, rising difficult dilemmas in the field of antiepileptic drug development, and even more after drug is being used in clinical practice.

Clinical trials with antiepileptic drugs designed according to the regulatory guidelines usually do not give sufficient prediction of their effectiveness and safety in clinical practice settings $^{3}$. Clinicians who have to prescribe new antiepileptic drug are frequently frustrated, because from the summary of product characteristics they cannot have clear understanding: is the drug effective as initial therapy, could it be used as mono-therapy, what is the optimal dosing regimen, what inter-individual differences could be expected in responsiveness to the drug, what are long-term effectiveness, tolerability and safety of the drug ${ }^{4}$. The situation is even more challenging when antiepileptic drugs are to be prescribed to children, especially in regard to the generalized seizures and epilepsy syndromes encountered only in childhood ${ }^{5}$.

The aim of this review is to focus on the gaps in current knowledge about optimal use of new antiepileptic drugs in clinical practice, and to suggest changes in regulatory procedures for clinical development of these drugs which could result with improved treatment of patients with epilepsy.

\section{METHODS}

In order to identify articles on methodology and regulatory guidelines of clinical trials with anticonvulsants the following databases of scientific articles were searched: MEDLINE ${ }^{6}$, SCOPUS $^{7}$ and SCINDEKS ${ }^{8}$. The following combinations of keywords were used: "clinical investigation + anticonvulsants + guidelines", "clinical investigation + drug development + epilepsy" and "medicinal products + development + epilepsy + regulation", including all records from 1969 to 2015. The types of articles selected among the retrieved papers were reviews, reports on clinical trials and letters to the Editor.

The combination of keywords "clinical trial + anticonvulsants + guidelines" retrieved 287 publications from MEDLINE, 558 from SCOPUS and 0 from SCINDEKS; the combination "clinical investigation + drug development + epilepsy" retrieved 53 publications from MEDLINE, 213 from SCOPUS and 2 from SCINDEKS. Finally, the combination of keywords "medicinal products + development + epilepsy + regulation" retrieved 15 publications from MEDLINE, 3 from SCOPUS and 0 from SCINDEKS.

\section{ADD-ON TRIALS}

The add-on clinical trials where an investigational antiepileptic drug is added to antiepileptic therapy which a patient received for a long time, but it did not completely controlled the seizures, are usually the first to be undertaken during clinical development of an anticonvulsant. The pool of potential patients is large, since the existing antiepileptic drugs cannot achieve complete control of seizures in many patients. The patients with partial seizures with or without secondary generalization are usually chosen first, and later trials include the patients with primary generalized seizures. The add-on trials use placebo as comparator, since it could not make additional harm, while it is not known whether any additional therapy (including the investiga- 
tional drug) will improve the patient's condition. Whenever possible, the add-on trials include demonstration of dose-response relationship, which is an additional proof of efficacy ${ }^{9}$.

The only regulatory issue with the add-on trials is question of cross-over design. Although used a lot in the past, the cross-over design is now considered inappropriate as primary proof of anticonvulsant efficiency ${ }^{10}$. If a patient is to be switched from one treatment regimen to another, during the washout period seizure frequency and severity should return to baseline values. This is sometimes difficult to achieve because there are individual, periodic changes in the disease activity regardless of the therapy, and certain antiepileptic drugs are more prone to carry-over effect from first to the second study period. Besides, if a patient was well on the first therapy regimen, it could be unethical to switch her/him to less efficient second regimen, not to mention that despite of blinding the patient will understand when she/he was taking placebo or the investigational drug ${ }^{11}$. Therefore, majority of regulatory bodies prefer that parallel group design should be used for add-on trials.

The preference of regulatory agencies towards parallel groups design for add-on trials should be made more explicit in the guidelines for clinical development of antiepileptic drugs. This would direct sponsors on time to avoid cross-over design and methodological issues it carries, but to start from the very beginning with the design which will bring higher level of evidence.

\section{THE PROBLEM OF MONOTHERAPY TRIALS}

Since the add-on clinical trials with antiepileptic drugs recruit the patients with chronic refractory epilepsy, their results cannot be extrapolated to new, treatment-naïve patients (the patients who did not take anticonvulsants prior the current clinical trial), who are in many ways different from the former group ${ }^{12}$. Establishing efficacy of an anticonvulsant as monotherapy is difficult to achieve during clinical drug development due to low availability of treatmentnaïve patients with epilepsy who are ready to be enrolled in a clinical trial. Usual way to overcome this problem is to use conversion or presurgical withdrawal-type design of clinical trials with short duration. In conversion design the outpatients stabilized on certain anticonvulsant medication at first receive adjunctive therapy with either investigational anticonvulsant (usu- ally both high and low doses) or comparator, and then the baseline anticonvulsants are gradually withdrawn, until the patients remain on monotherapy ${ }^{13}$. The comparator is usually another antiepileptic drug or low-dose regimen of the investigational drug (so called "pseudoplacebo"), use of true placebo is ethically unacceptable, since the patients in the placebo arm could have worsening of their condition with grave consequences: injuries, decreased working capacity, psychological problems, etc. Primary efficacy outcome in such studies is treatment retention time, i.e. time which elapsed until the patient's condition worsened up to a predefined degree. While the FDA accepts this type of trials for the purpose of granting marketing approval to the investigational drug for withdrawal-to-monotherapy in refractory patients, the EMA still requires monotherapy trials with treatment-naïve patients $^{3,4,5}$. In order to make withdrawal-tomonotherapy type of clinical trials more feasible, the FDA now accepts the results of previous studies as "historical controls" for establishing efficacy and safety of new drugs in patients who were stable, but not seizure-free on a single anticonvulsant. The first drug that was granted marketing authorization for monotherapy after the studies with historical controls was extendedrelease formulation of lamotrigine ${ }^{14}$.

Presurgical withdrawal studies use the opportunity created when inpatients with epilepsy who are prepared for surgical treatment discontinue their prior antiepileptic drugs during diagnostic process of localizing seizures. Then the patients receive either investigational drug or placebo, and are maintained on such therapy until their condition is worsened according to previously defined criteria (e.g. certain frequency of seizures, increase in severity of seizures) ${ }^{15}$.

Both conversion-type and presurgical withdrawal designs are actually "proof-of-concept" studies which cannot give information about long-term efficacy of an investigational drug, due to their short duration in the first place ${ }^{16}$. Therefore, in order to be granted approval for monotherapy in patients which are not treatmentresistant, investigational antiepileptic drugs have to be tested in monotherapy trials with treatmentnaïve patients. Such trials are using parallelgroup design with active control (use of placebo in such settings is ethically problematic, since the patients would not have any benefit of participation in a trial like this). These patients are not drug resistant (unlike the patients in add-on trials) and a delay in receiving the appropriate treatment may only worsen their clinical con- 
dition. Although resource-demanding, monotherapy trials in treatment-naïve patients are longterm and give unique opportunity to establish efficacy of the investigational drug and to compare it head-to-head with already established antiepileptic drugs. However, while the EMA imposed realistic requirements demanding that an investigational drug only should not be less effective of the comparator (the best existing therapy), i.e. the non-inferiority design is acceptable, the FDA requires from the investigational drugs to demonstrate superiority over the comparator ${ }^{17}$. This regulatory request require large sample size, especially when the comparator is truly effective (as it is usually the case nowadays). Before the onset non-inferiority trials the extent of meaningful difference in efficacies of the investigational drug and comparator should be set. The difference, which should be shown as non-existent in these trials, is usually $10 \%$ of the value of the main study end-point ${ }^{18,19}$.

Although monotherapy trials on treatmentnaïve patients with epilepsy cannot be avoided, clinical development of new antiepileptic drugs would become more productive if all major drug agencies (including the FDA) accept the noninferiority design in their guidelines as standard requirement for such clinical trials. The trials would enroll less treatment-naïve patients, and their cost and duration would decrease (because the overall enrollment period for the whole trial would be of less duration), shortening time necessary for obtaining regulatory approval. True effectiveness of new antiepileptic drugs would then be established by carefully designed observational studies, as it was already the case with older anticonvulsants ${ }^{20}$.

\section{TESTING ANTIEPILEPTIC DRUGS IN CHILDREN}

Current guidelines for clinical development of antiepileptic drugs either preclude participation of children with age-nonspecific epilepsies (i.e. with seizures types other than absence, infantile spasms and akinetic seizures) in clinical trials until late phase II or phase III (FDA), or suggest short-term trials in children younger than 4 years and suffering from non-specific epilepsies (focal epilepsies, especially cryptogenic and symptomatic, and idiopathic generalised epilepsies, with absences, myoclonic and/or generalised convulsive seizures) with EEG surrogate end points (EMA) ${ }^{1,2}$. Children should be included in early clinical trials only after safety studies were already conducted in adults. EMA also suggests that children with age-specific epilepsies (e.g. West syndrome, Dravet syndrome, myoclonic-astatic epilepsy, Lennox Gastaut Syndrome and Continuous Spike-Wave in Slow Sleep syndromes) should be enrolled in add-on clinical trials as soon as the dose for children has been established. According to EMA requirements, at least 100 pediatric patients should be followed for a year or longer in order to establish safety of new anticonvulsant in children. However, these requirements are not based on evidence of adverse consequences of enrolling children with age-nonspecific epilepsies in early clinical trials, and on the other hand, without pharmacokinetic data, optimal dosing information and tolerability data gathered from a pediatric clinical trial it is very difficult to administer antiepileptic drug optimally to this vulnerable population ${ }^{5,21,22}$. Regulatory documents should be less restrictive when trials of antiepileptic drugs in children are in question, the sponsors will then have more options for clinical development of their drugs and the trial results will be more useful for pediatric clinical practice.

However, some current regulatory requirements that apply for drugs intended for use in children in general may be helpful in the meantime. Extrapolation of results from clinical trials in adults to children is allowed in U.S.A. if a drug is thought to act in the same way to similar condition in both adults and children, and such drug may be licensed with small additional pediatric studies. Besides, for certain drugs (listed by the FDA) market exclusivity could be prolonged for 6 months if a pediatric clinical trial is done ${ }^{23}$.

\section{TRIAL END POINTS}

The regulatory acts require the following measures of efficacy to be used in clinical trials with antiepileptic drugs: fraction of patients without seizures for at least six months, percentage of patients with reduction of seizure frequency for less than $25 \%, 25-50 \%, 50-75 \%$ and more than $75 \%$, seizure severity, treatment retention time, scales for working and social capacity and EEG patterns for specific epilepsy types $^{1,2}$. Some additional measures of efficacy should also be mentioned in the regulatory documents, since they could make administration of new antiepileptic drugs in clinical practice much easier. For example, number of seizurefree days, time not only to the first, but also to the nth seizure, and change in seizure frequency expressed as continuous parameter should also 
be used as outcome measures in clinical trials ${ }^{19,22}$. Especially quality of life should be taken into account as an outcome measure ${ }^{23}$. However, the end points should be specified for each of different populations of patients separately, since they cannot be used interchangeably. Additional measures of efficacy will increase sensitivity of clinical trials for revealing more subtle, yet important, differences in efficacy of the investigational drug compared with alternative therapy. It will also give better overall picture of the new drug's clinical utility. Since the FDA and EMA guidelines differ in requirements concerning efficacy measures, their harmonization in this sense would beneficially affect sponsors, who frequently develop their drugs for both "new" and "old world" markets.

\section{SAFETY ISSUES}

More proactive attitude towards discovery of adverse events should be explicit in regulatory documents, in order to avoid overlooking of frequent functional adverse actions of antiepileptic drugs ${ }^{24}$. The regulatory documents only mention that special attention should be paid to central nervous system adverse effects of antiepileptic drugs, but specific requirements are not set $\mathrm{up}^{1,2}$. Many validated scales for measurement of potential central adverse effects of antiepileptic drugs (with excellent psychometric properties) are now available for precise measurement of anxiety, depression, cognition, and quality of life in general ${ }^{25,26}$. Such instruments should be stated in the regulatory acts, at least as examples, in order to stimulate their use in practice. In the past, some central adverse effects were discovered only after the marketing authorization was obtained $^{27}$, and it could have been done much earlier with proactive use of measurement scales during the process of clinical development of all new anticonvulsants, both for adults and children. However, it should be taken into account that the uses of validated scales for measurement of potential central adverse effects could sometimes lead to an increase in the number of reported adverse events.

\section{EPILEPTOGENESIS}

Preclinical testing of antiepileptic drugs includes specific assays which may discover not only anticonvulsant, but also anti-epileptogenic effect of an investigational $\operatorname{drug}^{28}$. Although there are drugs which are not anticonvulsants, but have anti-epileptogenic properties, some of the anticonvulsants may have anti-epileptogenic action, too (e.g. anti-absence drug ethosuximide), which is important to know if such a drug is going to be used for prophylactic purposes (e.g. after neurosurgery ${ }^{29}$. Ideal clinical trial investigating anti-epileptogenic properties of an anticonvulsant should include patient population with very high epilepsy risk (e.g. patients with traumatic brain injury), it should be clear which factor and when causes epilepsy and there should be short latency from the moment when causative factor starts its action until the onset of seizures $^{30}$. However, regulatory documents do not require clinical trials specifically designed to prove anti-epileptogenic effects. Specific guidance for this type of clinical trials would be very useful for sponsors, and probably would widen approved indications for new antiepileptic drugs. The design of antiepileptogenic trials should have two phases: the first, parallel groups phase, which would estimate antiseizure effect, and second phase after washout of the drug, which would show prevention against emergence of new seizures without the drug present in the blood for at least 2 years ${ }^{29,31,32,33}$.

\section{CONCLUSIONS}

Current regulatory documents are incomplete in many aspects, and in a few instances make unnecessary obstacles to clinical development of anticonvulsants. An international effort to improve and harmonize guidelines for clinical development of antiepileptic drugs is necessary, and probably will result with improvement of this process in respect of both efficacy and quality. The harmonization should be guided and possibly managed (hopefully with financial support from national drug agencies) by one or more of the leading international professional organizations devoted to studying epilepsy and transferring acquired knowledge to clinical practice, like International League against Epilepsy, which recently celebrated its Centenary anniversary. Besides, this process should be tuned with efforts on international harmonization of requirements for drug registration at national Drug Agencies undertaken by The International Conference on Harmonization of Technical Requirements for Registration of Pharmaceuticals for Human Use.

\section{ACKNOWLEDGMENTS}

This study was partially supported by grant No 175007 from Serbian Ministry of Education and by grant No 404 from Montenegrin Ministry of Science. 


\section{REFERENCES}

1. Guideline on clinical investigation of medicinal products in the treatment of epileptic disorders. European Medicines Agency, 22 July 2010, CHMP/EWP/566/98 Rev.2/Corr, Available at: http://www.ema.europa.eu/docs/en_GB/document_libr ary/Scientific_guideline/2010/01/WC500070043.pdf, [Last accessed 22 February 2015].

2. Guidelines for the Clinical Evaluation of Antiepileptic Drugs (Adults and Children). U.S. Department of Health and Human Services, Public Health Service, Food and Drug Administration. Available at: http://www.fda.gov/downloads/drugs/guidancecomplia nceregulatoryinformation/guidances/ucm071582.pdf, [Last accessed 22 February 2015].

3. Schmidt B. Clinical development of antiepileptic drugs in adults. Neurotherapeutics 2007; 4(1): 62-9.

4. Faught E. Antiepileptic drug trials: the view from the clinic. Epileptic Disord 2012; 14(2): 114-23.

5. Garofalo E. Clinical development of antiepileptic drugs for children. Neurotherapeutics 2007; 4(1): 70-4.

6. MEDLINE database of scientific articles; Available at: http://www.ncbi.nlm.nih.gov/pubmed, [Last accessed 4. June 2015].

7. SCOPUS database of scientific articles; available at: http://www-scopus-com.proxy.kobson.nb.rs:2048/, [Last accessed 4. June 2015].

8. SCINDEKS database of medical journals,available at: http://scindeks.ceon.rs/?lang=en, [Last accessed 4. June 2015].

9. Schobben F, Hekster Y, van Zwieten-Boot B. Outcome measures for the assessmentof new antiepileptic drugs. Pharm World Sci 1997; 19(5): 223-6.

10. Pulman J, Hutton JL, Marson AG. Tiagabine add-on for drug-resistant partialepilepsy. Cochrane Database Syst Rev 2014; 2: CD001908.

11. Beydoun A, Uthman BM, Kugler AR, et al; Pregabalin1008-009 Study Group. Safety and efficacy of two pregabalin regimens for add-ontreatment of partial epilepsy. Neurology 2005; 64(3): 475-80.

12. Kwan P, Brodie MJ. Clinical trials of antiepileptic medications in newly diagnosed patients with epilepsy. Neurology 2003; 60(11 Suppl 4): S2-12.

13. Kälviäinen R. Monotherapy trial design: conversion versus de novo. Epilepsy Res 2001; 45(1-3): 75-8.

14. Brodie MJ. Novel trial designs for monotherapy. Epileptic Disord 2012; 14(2): 132-7.

15. Lee BI. Ethical issues of using placebo in antiepilepticdrugs trials in Asia. Neurology Asia 2010; 15 (Supplement 1) : $29-31$.

16. French JA, Cabrera J, Emir B, et al. Designing a newproof-of-principle trial for treatment of partial seizures to demonstrateefficacy with minimal sample size and duration-a case study. Epilepsy Res 2013; 106(12): 230-6.

17. Perucca E. When clinical trials make history: demonstrating efficacy of newantiepileptic drugs as monotherapy. Epilepsia 2010; 51(10): 1933-5.

18. Liu SY, Yang XL, Chen B, et al. Clinical outcomes andquality of life following surgical treatment for refractory epilepsy: asystematic review and metaanalysis. Medicine (Baltimore) 2015; 94(6): e500.
19. Bien CG, Elger CE. Monotherapy trials in antiepileptic drugs: are modified "presurgical studies" a wayout of the dilemma?. Epilepsy research 2001; 44(1): 15.

20. Mattson RH, Cramer JA, Collins JF, et al. Comparison ofcarbamazepine, phenobarbital, phenytoin, and primidone in partial and secondarilygeneralized tonic-clonic seizures. N Engl J Med 1985; 313(3): 145-51.

21. Mohanraj R, Brodie MJ. Measuring the efficacy of antiepileptic drugs. Seizure 2003; 12(7): 413-43.

22. Amann JP, Glauser T, Chiron C. Developing antiepileptic drugs in children:balancing protection and access. Handb Clin Neurol 2013; 111: 741-6.

23. Conroy S, McIntyre J, Choonara I, et al. Drug trials in children:problems and the way forward. $\mathrm{Br} \mathrm{J}$ Clin Pharmacol 2000; 49(2): 93-7.

24. Pellock J. Antiepileptic drugs trials: neonates and infants. Epilepsy Res 2006; 68(1): 42-5.

25. Rahman Z, Wong CH, Dexter M, et al. Epilepsy in patients with primary brain tumors: The impacton mood, cognition, and HRQOL. Epilepsy Behav 2015; 48: 88-95.

26. Gelenberg AJ. Using assessment tools to screen for, diagnose, and treat major depressive disorder in clinical practice. J Clin Psychiatry 2010; 71 SupplE1: e01.

27. Mattson RH. Cognitive, affective, and behavioral side events in adults secondary to antiepileptic drug use. Rev Neurol Dis 2004; 1 Suppl 1: S10-7.

28. Ijff DM, Aldenkamp AP. Cognitive side-effects of antiepileptic drugs in children. Handb Clin Neurol 2013; 111: 707-18.

29. Trinka E, Brigo F. Antiepileptogenesis in humans: disappointing clinicalevidence and ways to move forward. Curr Opin Neurol 2014; 27(2): 227-35.

30. Schmidt D. Is antiepileptogenesis a realistic goal in clinical trials? Concerns and new horizons. Epileptic Disord 2012; 14(2): 105-13.

31. Mani R, Pollard J, Dichter MA. Human clinical trails in antiepileptogenesis. Neurosci Lett 2011; 497(3): 251-6.

32. Kramer LD, Pledger GW, Kamin M. Prototype antiepileptic drug clinical development plan. Epilepsia 1993; 34(6): 1075-84.

33. Friedman D, French JA. Clinical trials for therapeutic assessment ofantiepileptic drugs in the 21st century: obstacles and solutions. Lancet Neurol 2012; 11(9): 827-34. 